\title{
Revenue and Expenditure Structure of Vyas Municipality
}

\author{
Devi Lal Sharma
}

\begin{abstract}
The local governments or the municipalities are responsible to provide administrative services to the local level and to develop infrastructures to provide physical facilities to municipal people. Thus, the major functions of the municipalities are the building up the infrastructure and supra structure and protecting public places and so on. To conduct such philanthropic works it is essential to sustain themselves financially. This study has intense relation with revenue and expenditure of Vyas Municipalities regarding the objectives to analyze, examine and interpret the Revenue and Expenditure. Descriptive research design has been adopted to conduct present study. Under the descriptive research design this study focuses on analyzing income and expenditure pattern of Vyas municipality thus case study approach has been followed to conduct this research. There are 243 municipalities in Nepal which are considered as the population of this study. Among them Vyas municipality is taken as sample using convenience sampling method. This study focuses on municipal revenue and expenditure thus based on secondary data. Vyas municipality largely depends upon the revenue raised from external sources to fulfill the financial requirements. The total revenue has been occupied by internal revenue and external revenue. The average growth rate of internal revenue has been greater than external revenue during the study period. Vyas municipality itself has been suffering from financial inadequacy. So unnecessary expenditure made for the consumption purpose should be cut off. Expenditure made for unproductive sectors should be minimized and utilized effectively.
\end{abstract}

Keywords: expenditure, financial strength, income, local government, Vyas municipality

\section{Context and Literature}

In Nepal, the recent emphasis is given to decentralized administration. The overarching goal of decentralized governance is to promote governance, strengthening pluralistic democracy and reduce poverty (NDF, 2002). Decentralization is the process in which all the people of community consisting with different levels, casts and religions participate for making their local body, which incorporates the good governance by establishing the political stability.

Local governments usually have some of the same kind of powers as national governments do. They usually have some power to raise taxes, through these may be limited by central legislation. The question of Municipal Autonomy-which powers the local government has, or should have, and why-is a key question of public administration and governance. Common names for local for government entities include state, province, region, department, country, prefecture, district city, township, town, borough, parish, municipality, shire and village. However all these names are often used informally in different countries and local government 
is the legal part of central government (http://www.wikipedia.org). In context of Nepal, District Development Committee (DDC), Village Municipality (Gaunpalika) and Municipality represent the local government. As cities grow and decentralization becomes more common, local governments are assuming greater responsibility for providing and financing effective public services. However, local fiscal and financial capacity rarely keeps pace with these increasing responsibilities. As a result, municipalities have to confront some issues. First, municipalities must manage available resources more efficiently and responsively. Second, they must advocate for reforms in intergovernmental fiscal relationships so that functional responsibilities are clearly defined. Third, they must mobilize new resources and increase their capacity to borrow responsibly for investments in local services. And, fourth, they must seek ways of attracting private participation in the financing and delivery of local public services (Thakuri, 2012).

The local governments or the municipalities are responsible to provide administrative services to the local level and to develop infrastructures to provide physical facilities to municipal people. Thus, the major functions of the municipalities arc the construction and maintenance of motor able roads, making hospital, supply the clean drinking water, drainage, and provide the electricity and telephone facilities, street lighting, making and protecting public places and so on. Municipal finance is concerned with the preparation and the effective execution of budget. The secretary shall at the direction of mayor, prepares the annual budget of income and expenditure of the municipality prior to the beginning of each fiscal year and submit it to the municipality for its approval (LSGA, 1999). Municipal financial management is related to the collection of the resources required for the delivery of municipal services, allocation of those collected resource for different service heads and ensuring the efficient and effective use of municipal resources. Strengthening the municipal finance is very important. It is impossible to meet the growing needs of urban services and to develop the area in a planned way without doing improvement in the financial system. In broad sense finance is the science of money. Finance refers to the provision of monetary sources to operate a system; it may be sector, where it is required. During the period when finance was not separated from economics, finance got a narrow meaning that the finance meant the procuring only long term fund and excluded working capital management from its scope. Since the declaration of democracy, finance is emerged as a distinct and important discipline with more significant meaning. In modern time, finance is concerned with the investment decision, financing decision and their effective execution. Municipal financial management is a branch of public financial management, which basically aims to maximize the social wealth (Hepworth, 1992).

For the success of financial decentralization, both the central government and local government should follow the principle of subsidiary by identifying their responsibility (Ebel \& Yi lmaz, 2002). A number of factors contribute to the structural construction of municipal finance i.e., size and level of local political body, government control, funds from donor agencies, required infrastructures for the public services, pattern of the projecting the budget and so on. Similarly the functions assigned to the municipalities are yet another important factor for determining the scope and the scale of municipal finance. It is almost a universal phenomenon that the increasing involvement of the units of local government in nation building activities the flow of government grant in aid has also increased. 
Financial resources provide energy for the smooth operation of local government institution and stimulate their activities. In fact, financial resource is critical base without which even the viability existence of the LGs would be questionable. LGs have the right and responsibility to raise the financial resources through direct and indirect taxation. The LGs have been also given the facility of borrowing loans getting grants-in-aid from central government. The important principle of the local taxation are autonomy, accountability, localization of tax base, non-exportability, balance of interest responsiveness to local economic growth. Local government allows a lesser degree of financial autonomy with its dependence on government in regard to various facts of its fiscal activities (Muttalib \& Khan, 1982). A budget is a draft for projecting the future revenues and expenditures. It is the control mechanism of any financial aspects. The budget can also be used as a management and planning tool in order to control all the financial transactions.

The local government officers prepare the budget for the coming year on the basis of expansion and contraction in their services and the effects of price inflation on their spending (Chandler, 1991). The secretary shall at the direction of mayor, prepares the annual budget of income and expenditure of the municipality prior to the beginning of each fiscal year and submit it to the municipality for its approval (LSGA, 1999). The budget preparation depends upon the financial health of the local bodies, especially the possible income to be received by the local authorities in terms of taxes, grants, and charges. This still remains a provision of income received to be determined largely by the government policies which sometimes unclear until the budget plans during the year which are based on different assumptions concerning revenues. Government budget is affected by numerous variables such as the law of the country; inter governmental transfer, structure of the government, the national and regional economy, the nature of the services provided and the personality of the principal actions.

Revenue is the crucial elements in every institution. There are two primary sources of municipal revenue. The revenues collected themselves are known as internal sources of revenue. It includes local taxes, service charges, fees, rental income from buildings and facilities, interest income on municipal investment, income from sale of municipal assets. The other major source of revenue is external sources. It includes central government transfers and grants.

In present context, the intergovernmental transfer and grants are being reduced by the central government to the local bodies due the concept of decentralization. So the local entities have to exercise to increase the own sources of revenue rather to depend upon the central grant.

Vyas-Municipality is the headquarters of Tanahun District in the Gandaki Zone Western Nepal. At the time of 1991 Nepal census it had a population of 18,099 people residing in 3604 individual households. It's one of the well planned towns in Nepal. The beautiful town is growing fast to be one of the major cities in the country. Majority of the population are engaged in some kind of business. It is easily recognizable because it is located on the confluence of two major rivers the Madi and the Seti. The Manung hill is another important geographical landmark overlooking the Town (http://en.wikipedia.org/wiki/Damauli). 
Local governments or the local bodies are formulated to implement the concepts of decentralization. According to William A. Robson, "Local government may be said to in the value of conception of territorial non-sovereign humility possessing the legal rights and necessary organization to regulate its affairs. The Local government is a popularly elected council, chosen within the area administrated by the council is created for the management of local affairs and services. The concept of municipality in many parts of the world emerge as decentralization of central governments, departments and public utilities to be looked by regional outstations for better provision and regulation of services. The municipalities are the local level governments created for the urban areas to look after the local public affairs. People think that local self government means community government which coordinates the activities that are concerned with the local community. A local body represents not only the local opinion but also helps the central government to formulate genuine policies for the betterment of the locality and in term of the country (Thapa, 2003).

In municipalities, octroi tax or local development fee contributed to the total internal revenue to great extent. So there was higher possibility of identifying other sources of internal revenue. In his study period, the revenue generated was excess than the expenditure not due to the collection efficiency but due to the sufficient grant from government of Nepal, other international donor agencies, TDFB (Town Development Fund Board). So the municipality could make more investment on productive sectors by making proper mechanism (Chapagain, 1995). The financial autonomy should be provided to the local bodies for effective mobilization of financial resources. So that the local bodies can do more and better in terms of providing necessary facilities to local people (Timilsina, 1996). The octroi tax covered the internal revenue to large extent. Similarly vehicle tax was another important source of revenue collection. The municipality was receiving very low amount of grant from central government. The regular expenditure or operating expenditure was always higher than that of development expenditure. It means the municipality was not able to utilize the revenue generated in productive sector (Pahadi, 1997). Octroi tax and vehicle tax was found main sources of internal revenue collection. There was lack of proper and effective utilization of the funds available and more spending on non productive sector. The revenue collection and expenditure trend was not consistent due to ineffective mechanism (Silwal, 1998).

The development is only possible when available local resources are properly utilized. In his study any considerations was not made concerned to the financial performance of the Municipal Corporation (Subedi, 1999). The trend of enterprise tax was highly fluctuating due to the ineffective collection procedures and lack of appropriate legal action against tax defaulters. Similarly, the tax collection procedures were not effective or tax administration of PSMC was weak and only $31 \%$ of the total potential enterprise tax was collected. He recommended that tax payers should be identified, tax payers and tax rolls should be updated, effective billing system should be applied and should be improved and PSMC should promise to utilize the generated tax for the tax payers (Manandhar, 2001). The municipality was unable to utilize the generated funds in productive sectors (Pradhananga, 2002). The tax from local tax was fluctuating due to the ineffective tax collection system (Thapa, 2003). The municipality was also suffering from overstaffing problem and huge amount was spent on salaries, allowances, premium of insurance and to provide other facilities. Financial donation 
and assistance has been made on the basis of political biasness than real needs (Adhikari, 2004). The revenue collection and expenditure was fluctuated during his study period. The contribution of local tax revenue to the total revenue was higher than the non tax revenue. But institution was suffering from financial inadequacy. Lekhnath municipality was not applying specific tax to the specific tax zone but taking as professional tax. The budget formulated during his study period was unsystematic, unrealistic and overambitious (Pokharel, 2008).

The budget was not formulated upon budgetary norms and standard. The contribution of external revenue was higher in total revenue. Internal revenue was fluctuating due to the lack of internal revenue mobilization. The total revenue was in increasing trend. The budget was highly fluctuated due to the lack of study in depth and planning. It was also found the positive relation between budgeted performances of actual performances (Sigdel, 2008). Lekhnath municipality was largely depends upon the revenue raised from external sources to fulfill the financial needs. The correlation among budgeted and actual revenue and expenditure has been found very significant. The overall financial performance based on financial performance based on financial indicators has been found satisfactory. However, the budgeted revenue and expenditure have been found much higher than the actual figure. It means formulated budgets have been found unrealistic, unscientific and over ambitious (Thakuri, 2012). Internal revenue of Gorkha DDC was very weak and is highly dependent on external revenue. The financial indicators of Gorkha DDC are very poor. Most of the indicators are very weak in the study period. And the budgetary process of Gorkha DDC is unscientific, over ambitious and unrealistic (Lamdari, 2013). In FY 2065/66 onwards, budget and actual land revenue tax was increased significantly due to changes in the rate after authority granted by LSAGA and its regulation's reform. The trend of collecting revenue must be in increasing order due to increase in valuation of house and land in the market or government rate but the secondary data showed likely to be constant (Chhetri, 2014).

\section{Problem and Objective}

Since last a few decades, the migration rate has been increasing tremendously. Higher percentage of the rural people has been migrating to urban areas in search of opportunities and facilities. So the population is being increased in urban area. The local body or the municipality which is established for the development and the management of issues relating to general people of urban center has been facing serious problem especially financial problem. Due to inadequate financial sources, municipalities are being unable to address all the issues concern to public affairs. As other municipalities this municipality is also facing the financial problem. This study has tried to analyze and examine Revenue and Expenditure of Vyas Municipality. Furthermore the study has tried to answer what are the sources of revenues and its expenditure pattern of Vyas Municipality? To answer this question this study focuses on observing the sources of revenue and its expenditure pattern of Vyas Municipality. This study has intense relation with revenue and expenditure of Vyas Municipalities regarding the objectives to analyze, examine and interpret the Revenue and Expenditure. 


\section{Data and Methods}

Descriptive research design has been adopted to conduct present study. Under the descriptive research design this study focuses on analyzing income and expenditure pattern of Vyas municipality thus case study approach has been followed to conduct this research. There are 243 municipalities in Nepal which are considered as the population of this study. Among them Vyas municipality is taken as sample using convenience sampling method. This study focuses on municipal revenue and expenditure thus based on secondary data. The secondary sources include Annual budget/reports of Vyas municipality office, Records of municipality office, internally generated research reports and Meeting minutes of the board of Vyas municipality. In addition to these published reports concerned to the research topic, various dissertations concerned to the local government financial analysis, Websites and Internet and Newspapers, magazines and so on also used as the sources of information.

Annual budget reports of the municipality have been acquired from its office. Similarly, municipality records, notices and publications and meeting minutes have also been used. Some required data and information has been collected from regional library of Pokhara. Moreover, the required information has been gathered from different websites concerned to the topic. In this study, secondary data has been collected, presented in tables, charts and diagrams and such presentations have been interpreted as requirements. Similarly, to assess the structure of revenue and expenditure, composition analysis is used to show the relation among the variables. It includes data of only 5 years for the analysis from fiscal year 2066/067 to 2070/071. The different tools and techniques used for the analysis are based on certain assumptions. However, as samples with in a definite time span some limited data having included in analysis which does not represent absolute financial status. More over within it only qualitative tools analysis is used which doesn't represent quantitative assessment. But it surely gives a particular direction to the industry. Most data available from municipality seems to be dissimilar which pose ambiguity in recognized real statement of data.

\section{Discussion and Analysis}

The main objective of this study is to examine the present practice of revenue generation and its utilization in Vyas municipality. To achieve the said objective, this section focuses on the clear presentation of the detailed data that can exhibit the actual financial position of Vyas municipality. In this section, the composition, pattern, relation of revenue and expenditure and ultimately the financial performance of Vyas Municipality have been analyzed. For that, various tools and techniques have been used.

Vyas municipality has two major sources of revenue generation, i.e. internal and external sources. Internal source consists of tax and non-tax revenue and external source consists of grants and loans. The composition of internal and external sources is given below. 
Table 1: Revenue Analyses (Excluding B/F)

\begin{tabular}{rrrrrrrrrr}
\hline \multirow{2}{*}{ Fiscal Year } & \multicolumn{3}{c}{ Internal Revenue } & \multicolumn{3}{c}{ External Revenue } & \multicolumn{3}{c}{ Total Revenue } \\
\cline { 2 - 10 } & Amount & \multicolumn{1}{c}{$\%$} & Growth & \multicolumn{1}{c}{ Amount } & $\%$ & Growth & Amount & $\%$ & Growth \\
\hline $2066 / 067$ & 18764353.18 & 18.89 & - & 60475422.4 & 18.08 & & 79239775.6 & 18.27 & \\
$2067 / 068$ & 16452029.46 & 16.56 & -12.32 & 74020255.4 & 22.13 & 22.40 & 90472284.9 & 20.85 & 14.18 \\
$2068 / 069$ & 18635853.84 & 18.76 & 13.27 & 64239638 & 19.21 & -13.21 & 82875491.8 & 19.10 & -8.40 \\
$2069 / 070$ & 19745364.81 & 19.88 & 5.95 & 58373826 & 17.45 & -9.13 & 78119190.8 & 18.01 & -5.74 \\
$2070 / 071$ & 25732356.75 & 25.91 & 30.32 & 77378526 & 23.13 & 32.56 & 103110883 & 23.77 & 31.99 \\
Average Growth Rate & & 9.31 & & $100 \%$ & 8.15 & & & 8.01
\end{tabular}

Sources: Annual Reports, Vyas Municipality

Table 1 indicates total internal and external revenue from the fiscal year 2066/067 to 2070/071. The total internal revenue for the year $2066 / 067$ is 18764353.18 which are $18.89 \%$ of total revenue. In fiscal year 2067/068 the revenue is decreased by $2.33 \%$. The revenue fluctuates during other fiscal year and reached up to Rs 25732356.75 which is $25.91 \%$ of total internal revenue. On the other hand, the total external revenue for the year 2066/067 is 60475422.4 which are $18.08 \%$ of total external revenue. In fiscal year $2067 / 068$ the revenue is increases by $4.05 \%$, but it decreases in fiscal year $2068 / 069$ and $2069 / 070$ by 2.92 and 1.76 respectively. The revenue increases in $2070 / 071$ by 5.68 and reached up to 77378562 which is $23.13 \%$ of total external revenue. The data above indicate the revenue generated from internal and external sources are highly fluctuated during observed periods. The contribution of revenue raised from internal source ranged from $18.89 \%$ to $25.91 \%$. Similarly, the contribution of external revenue varies from $18.08 \%$ to $23.13 \%$ to the total revenue. It means, the contribution of revenue raised from external sources is much higher than that of internal sources. And average growth rate of internal, external and total revenue are $9.31 \%, 8.15 \%$ and $8.01 \%$ respectively.

It is the major sources of revenue of Vyas Municipality. It includes tax and non tax revenue. Tax revenue consists of local taxes and non tax revenue consists of fees and fines, property rental and miscellaneous income.

Table 2: Internal Revenue Analysis

\begin{tabular}{cccccccrr}
\hline \multirow{2}{*}{$\begin{array}{c}\text { Fiscal } \\
\text { Year }\end{array}$} & \multicolumn{3}{c}{ Tax Revenue } & \multicolumn{3}{c}{ Non Tax Revenue } & \multicolumn{2}{c}{ Internal Revenue } \\
\cline { 2 - 9 } & Amount & $\%$ & Growth & Amount & $\%$ & Growth & Amount & Growth \\
\hline $2066 / 067$ & 3370817.33 & 4.26 & - & 15393535 & 21.82 & -18764352.3 & \\
$2067 / 068$ & 4596980.97 & 17.31 & 75.36 & 11855048 & 16.81 & -29.85 & 16452029 & -0.45 \\
$2068 / 069$ & 5992249.61 & 22.56 & 23.28 & 12643604 & 17.93 & 6.24 & 18635853.6 & 11.72 \\
$2069 / 070$ & 6662577.16 & 25.09 & 10.06 & 13082788 & 18.55 & 3.36 & 19745365.2 & 5.62 \\
$2070 / 071$ & 8173532.25 & 30.78 & 18.49 & 17558825 & 24.89 & 25.49 & 25732357.3 & 23.27 \\
Average Growth Rate & 20 & & & 1.31 & & 10.04 \\
\hline
\end{tabular}

Sources: Annual Reports, Vyas Municipality

Table 2 shows the tax revenue is in increasing position in each five fiscal year. The revenue in $2066 / 067$ is 3370817.33 and reached up to 8473532.25 in the year $2070 / 071$. The non 
tax revenue is in decreasing position for first four fiscal year from 2066/067 to 2069/070 but it increases in 2070/071 which is $25.49 \%$ of total non tax revenue. Internal revenue consists of tax and non tax revenue. The tax and non-tax revenue are highly fluctuated during study periods. The contribution of tax revenue ranges from $4.62 \%$ to $30.78 \%$ where as the contribution of non-tax revenue varies from $21.82 \%$ to $24.89 \%$. Similarly, the average growth rate of tax revenue, non tax revenue and total internal revenue are $20 \%, 1.31 \%$ and $10.04 \%$ respectively.

L.S.G.A. 2058 gives authority to municipality to impose and collect tax from different sources. The revenue raised form tax consists of octroi tax (local development fees), land tax, house rent tax, vehicle tax, business tax, advertisement tax and other taxes.

Table 3: Tax Revenue Analysis

\begin{tabular}{|c|c|c|c|c|c|c|c|c|c|c|c|c|c|}
\hline \multirow{2}{*}{$\begin{array}{l}\text { Fiscal } \\
\text { Year }\end{array}$} & \multicolumn{2}{|c|}{$\begin{array}{l}\text { Land Tax } \\
\text { (Malpot) }\end{array}$} & \multicolumn{2}{|c|}{$\begin{array}{c}\text { House Land } \\
\text { Tax }\end{array}$} & \multicolumn{2}{|c|}{$\begin{array}{l}\text { House Rent } \\
\text { Tax }\end{array}$} & \multicolumn{2}{|c|}{ Business Tax } & \multicolumn{2}{|c|}{ Vehicle Tax } & \multicolumn{2}{|c|}{ Entertainment Tax } & \multirow{2}{*}{$\begin{array}{c}\text { Total } \\
\text { Amount }\end{array}$} \\
\hline & Amount & $\%$ & Amount & $\%$ & Amount & $\%$ & Amount & $\%$ & Amount & $\%$ & Amount & $\%$ & \\
\hline $2066 / 067$ & 2238141 & 11.2 & 162562 & 14.4 & 77573 & 8.4 & 617311 & 12.0 & 130210 & 13.0 & 145019 & 18.6 & 3370817 \\
\hline $2067 / 068$ & 3436964 & 17.2 & 187797 & 16.6 & 84013 & 9.1 & 627058 & 12.2 & 152305 & 15.2 & 108843 & 14.0 & 4596980 \\
\hline $2068 / 069$ & 4158750 & 20.8 & 288113 & 25.6 & 171042 & 18.6 & 1130114 & 22.1 & 141033.2 & 14.1 & 163196 & 21.0 & 6052249 \\
\hline $2069 / 070$ & 4676779 & 23.4 & 197310 & 17.5 & 200225 & 21.8 & 1199315 & 23.5 & 217805.9 & 21.8 & 171142 & 22.0 & 6662576 \\
\hline $2070 / 071$ & 5426788 & 27.2 & 289450 & 25.7 & 382254 & 41.7 & 1530642 & 29.9 & 356190.5 & 35.7 & 188206 & 24.2 & 8173531 \\
\hline
\end{tabular}

Sources: Annual Reports, Vyas Municipality

Table 3 classifies different types of tax revenue in which land tax, House rent tax, business tax are in increasing position but other tax like house land tax, vehicle tax and entertainment tax are decreases in 2069/070, 2068/069 and 2067/068 respectively. Tax revenue consists of different local taxes imposed and collected by the municipality. Tax revenue is also highly fluctuated during study periods. The contribution of land tax to the total local tax has been found very high and is ranged from $11.23 \%$ to $27.22 \%$. Similarly, business taxes are also fluctuated and respective contributions are varied from $12.09 \%$ to $29.99 \%$ during observed periods. But the contributions of other remaining taxes are not significant. The average growth rate of house land tax, house rent tax, business tax, vehicle tax and total local tax are, 25.77 $\%, 21.03 \%, 54.96 \%, 28.88 \%$ and $31.88 \%$ respectively.

Non-tax revenue is also another important source of internal revenue. It consists of fees and fines, property rental and miscellaneous income. The structure of non tax revenue is depicted in following table. 
Table 4: Non-Tax Revenue Analysis

\begin{tabular}{|c|c|c|c|c|c|c|c|}
\hline \multirow{2}{*}{ Fiscal Year } & \multicolumn{2}{|l|}{ Fees } & \multicolumn{2}{|c|}{ Property Rental } & \multicolumn{2}{|c|}{ Miscellaneous Income } & \multirow{2}{*}{$\frac{\text { Total Non Tax Revenue }}{\text { Amount }}$} \\
\hline & Amount & $\%$ & Amount & $\%$ & Amount & $\%$ & \\
\hline $2066 / 067$ & 3711606.27 & 13.4 & 6144879.5 & 16.96 & 210049.58 & 18.62 & 10066535.35 \\
\hline $2067 / 068$ & 5228315.05 & 18.8 & 6185919.21 & 17.08 & 440814.23 & 39.08 & 11855048.49 \\
\hline $2068 / 069$ & 5729669.53 & 20.6 & 6762956.29 & 18.67 & 150978.41 & 13.38 & 12643604.23 \\
\hline $2069 / 070$ & 5974756.96 & 21.5 & 6932271.44 & 19.14 & 175759.25 & 15.58 & 13082787.65 \\
\hline $2070 / 071$ & 7136071.21 & 25.7 & 10200289 & 28.16 & 150458.85 & 13.34 & 17486819.5 \\
\hline
\end{tabular}

Sources: Annual Reports, Vyas Municipality

Table 4 displays different types of non tax revenue they are fees, property rental, and miscellaneous income. Fees and property rental are increases from 13.4 to 25.7 and 16.96 to 28.16 respectively same as miscellaneous income is increase in the year $2067 / 068$ which is $39.08 \%$ of total miscellaneous income and start to decrease by $25.49 \%$ which is only $13.38 \%$ of total miscellaneous income. In fiscal year 2069/070 is slightly increases and again decrease in fiscal year $2070 / 071$ by $2.24 \%$ which is only $13.34 \%$ of the total. Non tax revenue consists of fees \& fines, property rental and miscellaneous income. The revenue from fees and fines is fluctuated and ranged from $13.4 \%$ to $25.7 \%$ during observed periods. Similarly, revenue raised from property rental also fluctuated and varied from $16.96 \%$ to $28.16 \%$ during five fiscal years. Likewise, the revenue from miscellaneous is also fluctuated and ranged from $17.77 \%$ to $33.66 \%$ during study periods. The average growth rate of fees \& fines, property rental, miscellaneous income and total non-tax revenue are $18.54 \%, 14.91 \%,-1.32 \%$ and $15.93 \%$ respectively.

External revenue is another important source of revenue generation of Vyas Municipality. It includes grants, i.e. Nepal government grants. T.D.F. grants, D.D.C. board grants and loans or borrowings, i.e. internal and external borrowings form employee's welfare fund, Nepal government, banks and other institutions.

Table 5: External Revenue Analysis

\begin{tabular}{|c|c|c|c|c|c|c|c|c|c|}
\hline \multirow{2}{*}{$\begin{array}{c}\text { Fiscal } \\
\text { Year }\end{array}$} & \multicolumn{3}{|c|}{ Grants } & \multicolumn{3}{|c|}{ Loan/Borrowing } & \multicolumn{3}{|c|}{ External Revenue } \\
\hline & Amount & $\%$ & Growth & Amount & $\%$ & Growth & Amount & $\%$ & Growth \\
\hline 2066/067 & 60475422.44 & 18.08 & & - & & & 60475422.44 & 18.08 & \\
\hline $2067 / 068$ & 74020255.42 & 22.13 & 22.40 & - & & & 74020255.42 & 22.13 & 22.40 \\
\hline $2068 / 069$ & 64239638 & 19.21 & -13.21 & - & & & 64239638 & 19.21 & -13.21 \\
\hline $2069 / 070$ & 58373826 & 17.45 & -9.13 & - & & & 58373826 & 17.45 & -9.13 \\
\hline $2070 / 071$ & 77378526 & 23.13 & 32.56 & - & & & 77378526 & 23.13 & 32.56 \\
\hline \multicolumn{3}{|c|}{ Average Growth Rate } & 32.61 & - & & & & & 32.61 \\
\hline
\end{tabular}

Source: Annual Reports, Vyas Municipality

External revenue consists of Grants and loan borrowing in which the average growth rate of grants revenue is $32.61 \%$. The growth rate of grants is decreases in fiscal year 2068/069 and $2069 / 070$ by 13.21 and 9.13 . After that it drastically increases by 32.56 in fiscal year 
$2070 / 071$ which is $23.13 \%$ of the total grants revenue. The municipality does not borrow any loan from any other sector. External source includes grants and loans/borrowings. Grants consists of administrative and development grants form NG, DOC, TDF and from foreign donor agencies. Similarly, municipality raises external revenue from internal as well as external borrowing. The revenue from grants and borrowings are highly fluctuated during study periods. The contribution of revenue from grants to the total external revenue ranges from $18.08 \%$ to $23.1 \%$. Likewise, the maximum contribution of loans and borrowing is not found during five fiscal years. The average growth rate of grants is $32.61 \%$. And external revenue has been growing with the rate of $32.61 \%$.

Municipalities spend their collected revenues to build infrastructures and to provide administrative services. Municipality should closely monitor and control the expenditure to minimize potential overruns. The expenditure of municipalities has two categories. One of them is current or regular expenditure, which includes consumption expenditure and administrative expenditure. Another one is development expenditure which includes expenditure made for social programs, ordinary capital and capital investment.

Table 6: Expenditure Analysis

\begin{tabular}{ccccccc}
\hline \multirow{2}{*}{$\begin{array}{c}\text { Fiscal } \\
\text { Year }\end{array}$} & \multicolumn{2}{c}{ Current Expenditure } & \multicolumn{2}{c}{ Development Expenditure } & \multicolumn{2}{c}{ Total Expenditure } \\
\cline { 2 - 7 } & Amount & $\%$ & Amount & $\%$ & Amount & $\%$ \\
\hline $2066 / 067$ & 11933661.07 & 13.06 & 65891218.86 & 19.31 & 77824880 & 17.99 \\
$2067 / 068$ & 13347121.57 & 14.61 & 81499771.77 & 23.88 & 94846893 & 21.92 \\
$2068 / 069$ & 20204701.22 & 22.11 & 63092318.09 & 18.49 & 83297019 & 19.25 \\
$2069 / 070$ & 21968608.67 & 24.04 & 51811124.88 & 15.18 & 73779734 & 17.05 \\
$2070 / 071$ & 23927799.12 & 26.18 & 78931159.79 & 23.13 & 102858959 & 23.78 \\
\hline
\end{tabular}

Source: Annual Reports, Vyas Municipality

Table 6 shows the Total expenditure of the Vyas Municipality which is divided into current and development expenditure. The current expenditure is in increasing rate for every year from 13.06 to $26.18 \%$. The average growth rate is 20.21 . The municipality invest more amount in development sector by which its cost goes increasing in fiscal year 2067/068 i.e. $23.88 \%$ of total development expenditure. The municipality reduces its cost in development expenditure coming fiscal year 2068/069 and 2069/070 and again it highly increases and reaches up to 52.34 in the fiscal year 2070/071. The expenditure of Vyas Municipality includes current and development expenditure. The development expenditure of municipality is much higher than the current expenditure. Both current and development expenditure has been fluctuated. During observed periods, the weight of current expenditure has been varied from $13.06 \%$ to $26.18 \%$. Similarly, the weight of development expenditure has ranged from $19.31 \%$ to 23.13 $\%$. The average growth rate of current and development expenditure and total expenditure are $20.21 \%, 8.89 \%$ and $9.42 \%$ respectively.

Current expenditure is short term in nature and occurred frequently. It covers consumption expenditure, i.e. salary; allowance, medical insurance premium, training expenditure and so on and administrative expenditure, i.e. water and electricity, telephone, rent, office operation, repair and maintenance expenditure and so on. 
Table 7: Current Expenditure Analyses

\begin{tabular}{crlrrrrr}
\hline \multirow{2}{*}{$\begin{array}{c}\text { Fiscal } \\
\text { Year }\end{array}$} & \multicolumn{2}{c}{$\begin{array}{c}\text { Consumption } \\
\text { Expenditure }\end{array}$} & \multicolumn{3}{c}{$\begin{array}{c}\text { Administrative } \\
\text { Expenditure }\end{array}$} & \multicolumn{2}{c}{ Current Expenditure } \\
\cline { 2 - 8 } & \multicolumn{1}{c}{ Amount } & $\%$ & \multicolumn{1}{c}{ Amount } & \multicolumn{1}{c}{$\%$} & Amount & $\%$ \\
\hline $2066 / 067$ & 6761155.72 & 11.80 & 5172505.35 & 15.17 & 11933661.07 & 13.06 \\
$2067 / 068$ & 6315183.7 & 11.02 & 7031937.87 & 20.63 & 13347121.57 & 14.61 \\
$2068 / 069$ & 14152330.15 & 24.70 & 6052371.07 & 17.75 & 20204701.22 & 22.11 \\
$2069 / 070$ & 13989777.37 & 24.42 & 7978831.3 & 23.40 & 21968608.67 & 24.04 \\
$2070 / 071$ & 16069403.4 & 28.05 & 7858395.72 & 23.05 & 23927799.12 & 26.18 \\
\hline
\end{tabular}

Source: Annual Reports, Vyas Municipality

The current expenditure is again divided into consumption and administrative expenditure. The increasing percentage of consumption expenditure is slightly fluctuated in each year and reach up to 28.05 from 11.80. The average growth of consumption expenditure is 32.81 . The municipality invests more in administrative sector in fiscal year 2067/068 than 2066/067 so it increases from 15.17 to 20.63 and again it decreases by 2.88 and again increases in coming fiscal year and reached up to 23.05. The average growth rate of administrative expenditure is 13.08. Current expenditure is classified into consumption and administrative expenditure. The proportion of consumption expenditure to the current expenditure is higher than administrative expenditure. Both expenditure are highly fluctuated and during study periods, consumption expenditure covers $11.80 \%$ to $28.05 \%$ and administrative expenditure occupies $15.17 \%$ to $23.05 \%$ to the total current expenditure. The average growth rate of consumption, administrative and current expenditure are $32.81 \%, 13.08 \%$ and $20.22 \%$ respectively.

Vyas Municipality spends generated revenue of developing infrastructures, to purchase furniture, machinery and to launch programs. Under this heads, expenditure made for social programs, purchase of ordinary capital and for capital investment is included.

Table 8: Development Expenditure Analysis

\begin{tabular}{|c|c|c|c|c|c|c|}
\hline \multirow{2}{*}{$\begin{array}{l}\text { Fiscal } \\
\text { Year }\end{array}$} & \multicolumn{2}{|c|}{ Social Program } & \multicolumn{2}{|c|}{$\begin{array}{l}\text { Capital Investment } \\
\text { Expenditure }\end{array}$} & \multicolumn{2}{|c|}{$\begin{array}{l}\text { Development } \\
\text { Expenditure }\end{array}$} \\
\hline & Amount & $\%$ & Amount & $\%$ & Amount & $\%$ \\
\hline $2066 / 067$ & 6526856.87 & 20.5 & 59364361.99 & 19.185 & 65891218.86 & 19.31 \\
\hline $2067 / 068$ & 6300914.87 & 19.8 & 75198856.9 & 24.302 & 81499771.77 & 23.88 \\
\hline $2068 / 069$ & 6244428.63 & 19.6 & 56847889.46 & 18.372 & 63092318.09 & 18.49 \\
\hline $2069 / 070$ & 6258479.91 & 19.7 & 45552644.97 & 14.721 & 51811124.88 & 15.18 \\
\hline $2070 / 071$ & 6463452.25 & 20.3 & 72467707.54 & 23.42 & 78931159.79 & 23.13 \\
\hline
\end{tabular}

Source: Annual Reports, Vyas Municipality

The municipality invests in its development sector like social program and capital investment. The amount invested in social program is 6526856.87 which is $20.5 \%$ of the total social 
program expenditure. Then after it remain at same percentage up to fiscal year2069/070. The average growth rate of social program is in negative which is 0.21 . The percentage of capital investment expenditure is 19.48 in first fiscal year and increases by 5.12, then after is decreases by 5.93. The ratio of capital expenditure is slightly decreases in 2069/070 and increases in 2070/071. The average growth rate of capital investment expenditure is only 10.37 because it has negative growth rate in two fiscal years i.e. 2068/069 and 2069/070. Development expenditure consists of expenditure made for social programs, for ordinary capital purchase and for capital investment. The weight of capital investment to development expenditure is almost $0.21 \%$. During observed periods municipality has not been expenditure on ordinary capital except in fiscal year 2067/068 and very nominal expenditure has made for social programs. Under capital investment heads, municipality spent its revenue on building constructions, to launch town level programs and for other constructions. There is fluctuation on expenditure made for the social programs and capital investment. The respective average growth rate of social programs and capital investment and total development expenditure are $0.21 \%, 10.37 \%$ and $8.89 \%$.

Financial indicators is a tools used to forecast the value or change in the value of another variable. For example changes in revenue are used to forecast the budgeted revenue in coming fiscal year. The table 9 shows the performance of own sources revenue, property rental, current expenditure, Capital investment, Social Development and grants in each and every fiscal year.

Table 9: Financial Indicators (As Prescribed by World Bank)

\begin{tabular}{|c|c|c|c|c|c|c|c|c|c|}
\hline \multirow{2}{*}{ Indicators } & \multicolumn{2}{|c|}{ Benchmark } & \multicolumn{6}{|c|}{ Fiscal Year: Municipality Performance (in \%) } & \multirow{2}{*}{ Remark } \\
\hline & Strong & Weak & $66 / 67$ & $67 / 68$ & $68 / 69$ & $69 / 70$ & $70 / 71$ & Average & \\
\hline $\begin{array}{c}\text { Own Sources } \\
\text { Revenue }\end{array}$ & $>75 \%$ & $<60 \%$ & 20.86 & 18.18 & 22.49 & 25.28 & 24.96 & 22.35 & very weak \\
\hline Property Rental & $>5 \%$ & $<3 \%$ & 37.18 & 37.60 & 36.29 & 35.11 & 39.64 & 37.16 & strong \\
\hline $\begin{array}{c}\text { Current } \\
\text { Expenditure }\end{array}$ & $<40 \%$ & $>43 \%$ & 15.33 & 14.07 & 24.26 & 29.78 & 23.26 & 21.34 & strong \\
\hline $\begin{array}{c}\text { Capital Investment } \\
+ \text { Social } \\
\text { Development }\end{array}$ & $>60 \%$ & $<40 \%$ & 84.67 & 85.93 & 75.74 & 70.22 & 76.74 & 78.66 & strong \\
\hline Net Effect & $<95 \%$ & $>100 \%$ & 98.21 & 104.84 & 100.51 & 94.45 & 99.76 & 99.55 & Average \\
\hline Grants & $<33 \%$ & $>50 \%$ & 76.32 & 81.82 & 77.51 & 74.72 & 75.04 & 77.08 & very weak \\
\hline Relative Growth & $>100 \%$ & $<100 \%$ & & & & & & 38.57 & very weak \\
\hline
\end{tabular}

Source: Annual Reports, Vyas Municipality \& World Bank Report 
The ratio of own source revenue with total revenue has been calculated $22.35 \%$ in average, which is very lower than the standards of World Bank and shows very weak performance. The weight of property rental to own source revenue has been found $37.16 \%$, which is above the standard developed by The World Bank and represents the strong position. The ratio of current expenditure has been found $21.34 \%$, which exhibits very strong position than the benchmark of The World Bank. Similarly, the average ratio of capital investment and social development has been found $78.66 \%$, which is above the level of benchmark and represents the strong performance. The ratio of net effect has been calculated $99.55 \%$ in average which is better than the standard developed by The World Bank and shows the average performance. Similarly, the average contribution of grants to the total revenue has been found $77.08 \%$, which is very higher than the level of standard and represents very weak performance. Finally, the performance of municipality in terms of relative growth has been found very weak with comparison to the standards of The World Bank.

\section{Conclusion}

Based on the above analysis, it can be conclude that Vyas municipality largely depends upon the revenue raised from external sources to fulfill the financial requirements. The total revenue has been occupied by internal revenue and external revenue. The average growth rate of internal revenue has been greater than external revenue during the study period. The increment on both revenue increases the gap between them. It can be seen that municipality has no financial autonomy and will be suffered from financial crisis if strong improvement cannot be made on internal revenue mobilization. The contribution of fees and other tax sources imposed by the municipality have very nominal contribution to the tax revenue. It means neither municipality able to utilize the identified sources of tax properly nor can identify other new sources which represent the poor collection efficiency of tax revenue. It is due to the lack of effective strategies and mechanism to collect the tax. The contribution of revenue raised from property rental to non-tax revenue has been found very nominal, which indicates that municipality ignores the revenue from property rental, which might be another important sources of internal revenue. The performance of municipality concerning to the current and development expenditure has been found very strong. But current expenditure has been allocating for consumption purpose to provide unnecessary services and facilities to the municipal staffs and municipal board members which only increases the financial burden to the municipality. And higher percentage of development expenditure has been used for construction and maintenance of building and other purchase, which is completely unproductive in nature. And it also ignores the social programs and others. It means, to great extent, Municipality is found irresponsible or unknown about own responsibilities concerning to the local people.

Vyas municipality must formulate some policies, mechanism and strategies for the effective mobilization of internal resources. Municipality has to introduce new sources of tax. For instance, parking tax, waste management tax, pollution controls tax etc. Other practiced sources of tax should be mobilized effectively. And property rental sources should not be kept aside while making the budget plan. Vyas municipality should identify the potential tax payers, launch some awareness programs about the tax liability and develop strong legal provisions against the tax defaulters. 


\section{BIBLOGRAPHY}

Adhikari, K. (2004). Financial analysis of local government: A case study on financial analysis of pokahra sub metropolitan city, Master Diss., Faculty of Management, P.N. Campus, Pokhara

Chandler, J. A. (1991). Local government today. Manchester; Manchester University Press, p.116

Chhetri, K. (2014). Tax revenue collection by local government of Nepal: A case study of Lekhnath Municipality. Master Diss., Faculty of Management P.N. Campus, Pokhara.

Ebel, R. D. \& Serdar, Y. (2002). The measurement and impact of fiscal decentralization. (Policy Research working Paper, World Bank, March) p.19

HMG /Nepal, Ministry of Local Development, Local self governance act. 1999

Hepworth, M. H. (1992). Book review: Innovation networks: Spatial perspectives. Roberto Camagnt (Ed.), 1991 London: Belhaven Press Retrieved from: journals.sagepub. com/doi/abs/10.1080/00420989220080951

Lamdari, L. (2013). Financial study of local governmence: A case study of the Gorkha District Development Committee. Master Diss., Faculty of Management P.N. Campus, Pokhara.

Manandhar, T. (2001). The enterprise tax: A case study of Pokhara Sub Municipal Corporation. Master Diss., Faculty of Management P.N. Campus, Pokhara.

Muttalib, M. A., \& Khan (1982). Theory of local government ( $1^{\text {st }}$ ed.). Delhi: Sterling Publishes. Grindley, N. D. F. (2002). The movement of Tn3-like elements: transposition and cointegrate resolution. In: Craig NL, Craigie R,

Pahadi, B. H. (1997). Municipality finance in Nepal: A case study of Janakpur Municipality. Masters Diss. Central Department of Economic. Tribhuvan University, Kathmandu.

Pokharel, M. (2008). A study on financial of local government: A study on financial analysis of Lekhanth Municipality. Master Diss. Faculty of Management, P.N. Campus, Pokhara

Pradhananga, S. (2002). Financial position of Dhangadi Municipality, Dhangadi. Master Diss. Faculty of Management, P.N. Campus, Pokhara

Sigdel, B. (2008). Financial analysis of local government: A case study of Tanahun District Development Committee. Master Diss., Faculty of Management, P.N. Campus, Pokhara

Silwal, S. (1998). Municipal finance in Nepal: A case study of Baglung Municipality. Masters Diss., Central Department of Economic Tribhuvan University, Kathmandu

Subedi, G. (1999). Local self government in Nepal: A case study of Pokhara Sub-Municipal Corporation. Master Diss., Department of Political Science, P.N. Campus, Pokhara

Thakuri, M. S. (2012). A study on municipal revenue and expenditure structure in Nepal: A case study of Lekhnath Municipality. Master Diss., Faculty of Management, P.N. Campus, Pokhara

Thapa, R. (2003). An assessment of Municipal Finance of Vimeshwor Municipality. Charikot, Dolakha District, Masters Diss., Tribhuwan University, Kathmandu.

Timilsina, R. N. (1996). Municipal finance in Nepal: A case study of Biratnagar Municipality. Masters Diss., Central Department of Economic, Tribhuvan University, Kathmandu http://www.wikepedia.com.np Retrieved 2015-5-30

http://en.wikipedia.org/wiki/Damauli

http://en.wikipedia.org/w/index.php?title $=$ List_of_cities_in_Nepal\&oldid $=722984048$

http://www.wikipedia.org 